\title{
Can Dental Caries be Defined as a Pandemic?
}

\author{
Vijay P Mathur ${ }^{1}$, Gauri Kalra ${ }^{2}$, Jatinder K Dhillon ${ }^{3}$ \\ Keywords: Caries, Epidemiology, Global, Pandemic. \\ Journal of South Asian Association of Pediatric Dentistry (2021): 10.5005/jp-journals-10077-3104
}

Dental caries has been named as universal disease which affects all human beings in all countries, continents, races, cultures, ethnicity, and genders. If it is left untreated, it progresses to destroy the tooth, its pulp as well as damaging the adjacent tissues. Sometimes the complications related to untreated dental caries can be serious and life threatening also.

According to the Global Burden of Disease 2017, dental caries in permanent teeth is the third most common health condition. Kassebaum et al. compiled the data from 154 countries over a period of 25 years and reported that dental caries is prevalent in $34.1 \%$ of adult population across the world. Although the age standardized prevalence of dental caries has remained stable from 1990-2015 on average but the distribution may have changed. ${ }^{1}$

A systematic review by Reifur KD et al. reported prevalence of $59 \%-90.4 \%$ worldwide in adolescents aged $15-19$ years, respectively. ${ }^{2}$ Younger aged children, being more vulnerable to this disease due to altered behavioral dietary patterns are found to have early involvement of teeth with dental caries. World Health Organization (WHO) has represented the early childhood caries as a worldwide oral health challenge with a prevalence between 60 and $90 \% .{ }^{3}$ In India, It has been further stated that early childhood caries also puts the permanent adult dentition at five times greater risk of developing caries. ${ }^{4}$ In the elderly population, root caries have been more common with the prevalence of more than $40 \%$. Further, various epidemiological studies have been carried out suggesting dental caries to be prevalent in both the genders and every strata of the communities, however, more prevalent in poor children or adults with limited resources. ${ }^{5,6}$ Lukacs JR studied in depth the magnitude and etiology of gender differences in caries incidence and found more caries rates in males as compared to females in South Asian region due to cultural factors. Hindu adult females had lower caries rates due to more dietary restrictions and frequent fasting. ${ }^{7}$ A report by CDC, 2018 accounted caries prevalence trends among youth aged 2-19 years in the United States to be $43.1 \%$ witnessing an increase with age from $17.7 \%$ among aged $2-5-45.2 \%$ among those aged $6-11$ to $53.5 \%$ in aged $12-19$ years. The report also suggested racial differences in caries distribution as $52 \%$ in Hispanic youth, Hispanic black (44.3\%), non-Hispanic Asian (42.6\%), and non-Hispanic white (39.0\%) youth, respectively. ${ }^{8}$ In Southeast Asian countries, studies ranging from 1984-2008, has reported an average DMFT score of 1.95 , with more caries prevalence in India and Thailand, followed by Nepal and Sri Lanka whereas an average of DMFT of 2.3 was found in European countries as per the results of studies conducted from 1973-2008 demonstrating a pervasive distribution of decay throughout the globe. ${ }^{9}$

With such an extensive data of dental caries affecting almost all age-groups, across the gender, all races, religions and ethnicity and crossing the boundaries of countries and continents in the
${ }^{1}$ Division of Pedodontics and Preventive Dentistry, Centre for Dental Education and Research, All India Institute of Medical Sciences, WHO Collaborating Centre for Oral Health, New Delhi, India

${ }^{2}$ Department of Pedodontics, Sudha Rustagi College of Dental Sciences and Research, Faridabad, Haryana, India

${ }^{3}$ Department of Pedodontics and Preventive Dentistry, Maulana Azad Institute of Dental Sciences, Delhi, India

Corresponding Author: Gauri Kalra, Department of Pedodontics, Sudha Rustagi College of Dental Sciences and Research, Faridabad, Haryana, India, Phone: +91 9910329898, e-mail: drgauri_dentist@yahoo.co.in

How to cite this article: Mathur VP, Kalra G, Dhillon JK. Can Dental Caries be Defined as a Pandemic? J South Asian Assoc Pediatr Dent 2021;4(3):163-164.

Source of support: Nil

Conflict of interest: None

world. There is a substantial impact of dental caries on quality of life, psychological health and economy of the people. Many of researchers and academicians debate over naming dental caries as a pandemic so that the policymakers and Governments can be influenced. However, despite being widely prevalent and extensively affecting people's lives, it does not qualify to be pandemic disease as per the definition. In the present article, we are trying to poise the legitimacy of the same.

As per Wikipedia, "A pandemic is an epidemic occurring on a scale that crosses international boundaries, usually affecting people on a worldwide scale. A disease or condition is not a pandemic merely because it is widespread or kills many people; it must also be infectious." Similarly, The International Epidemiology Association's Dictionary of Epidemiology also defines a pandemic as "an epidemic occurring worldwide, or over a very wide area, crossing international boundaries and usually affecting a large number of people". ${ }^{10}$ Based on this definition, dental caries crosses international borders, usually affects people at worldwide scale but it not infectious in nature. It can be transmitted from family member or mother to child as bacterial inoculum indirectly, which may or may not result into development of caries. There are several primary and secondary factors required for initiation of caries even after bacterial transfer. This transmissibility may not be termed as infectious and therefore, dental caries cannot be termed as pandemic. Dental caries is a multifactorial disease which depends on equilibrium of causative factors such as diet, micro-organisms or protective factors such as Fluoride and other remineralization factors. It is amenable to prevention and management at individual as well as mass levels. Due to the above, the authors propose that rather than trying to form dental

(c) The Author(s). 2021 Open Access This article is distributed under the terms of the Creative Commons Attribution 4.0 International License (https://creativecommons. org/licenses/by-nc/4.0/), which permits unrestricted use, distribution, and non-commercial reproduction in any medium, provided you give appropriate credit to the original author(s) and the source, provide a link to the Creative Commons license, and indicate if changes were made. The Creative Commons Public Domain Dedication waiver (http://creativecommons.org/publicdomain/zero/1.0/) applies to the data made available in this article, unless otherwise stated. 
caries into "pandemic," a new term for this disease can be used by the name of "Globendemic." This term can be defined as "as a disease which is present in all countries, during all seasons and affecting all populations." There is a need to augment advocacy with policymakers, Governments, funders, and common man using this new term so that adequate provisions can be made for prevention of this disease.

\section{References}

1. Kassebaum NJ, Smith AGC, Bernabé E, et al. Global, regional, and national prevalence, incidence, and disability-adjusted life years for oral conditions for 195 countries, 1990-2015: a systematic analysis for the global burden of diseases, injuries, and risk factors. J Dent Res 2017;96(4):380-387. DOI: 10.1177/0022034517693566

2. Reifur KD, De Oliveira Piorunneck CM, Moyses SJ. Dental caries and treatment needs in adolescents aged 15 to 19 years old and their relationship with dental services: a systematic review. Dent Health Curr Res 2017;3(2):0886-2470. DOI: 10.4172/2470-0886.1000129

3. Hallett KB, O'Rourke PK. Pattern and severity of early childhood caries. Community Dent Oral Epidemiol 2006;34(1):25-35. DOI: 10.1111/j.1600-0528.2006.00246.x
4. Meyer F, Enax J. Early childhood caries: epidemeology, aetiology and prevention. Int J Dent 2018 May 22. Retrieved from https://www. ncbi.nlm.nih.gov/pmc/articles/PMC5987323/\#B90.

5. Shaffer JR, Wang X, McNeil DW, et al. Genetic susceptibility to dental caries differs between the sexes: a family-based study. Caries Res 2011;49(2):133-140. DOI: 10.1159/000369103

6. Kazeminia M, Abdi A, Shohaimi S, et al. Dental caries in primary and permanent teeth in children's worldwide, 1995 to 2019: a systematic review and meta-analysis. Head Face Med 2020;16(1):22. DOI: 10.1186/s13005-020-00237-z. PMID: 33023617; PMCID: PMC7541284.

7. Lukacs JR. Gender differences in oral health in South Asia: metadata imply multifactorial biological and cultural causes. 2011;23(3):398-411. DOI: 10.1002/ajhb.21164

8. Fleming $E$, Afful J. Prevalence of total and untreated dental caries among youth: United States, 2015-2016. NCHS Data Brief 2018;(307):1-8.

9. Da Silveira Moreira R. Epidemiology of dental caries in the world. Oral Health Care-Pediatric, Research, Epidemiology and Clinical Practices 2012;8:149-168. DOI: 10.5772/31951

10. Porta, M. A Dictionary of Epidemiology (Oxford University Press, USA, 2008).https://www.oxfordreference.com/view/10.1093/ acref/9780195314496.001.0001/acref-9780195314496. 